\title{
Temperature Trends on Gran Canaria (Canary Islands). An Example of Global Warming over the Subtropical Northeastern Atlantic
}

\author{
Angel Luque ${ }^{1}$, José L. Martín ${ }^{2}$, Pedro Dorta ${ }^{3 *}$, Pablo Mayer ${ }^{4}$ \\ ${ }^{1}$ Image Processing and Remote Sensing Group, University of Las Palmas de Gran Canaria, Las Palmas de Gran Canaria, Spain \\ ${ }^{2}$ Canary Islands Agency for Climate Change and Sustainable Development, Sustainable Development Observatory, \\ Santa Cruz de Tenerife, Spain \\ ${ }^{3}$ Geography Department, University of La Laguna, San Cristóbal de La Laguna, Spain \\ ${ }^{4}$ Geography Department, University of Las Palmas de Gran Canaria, Las Palmas de Gran Canaria, Spain \\ Email: *pdorta@ull.es
}

Received October 15, 2013; revised November 11, 2013; accepted November 18, 2013

Copyright (C) 2014 Angel Luque et al. This is an open access article distributed under the Creative Commons Attribution License, which permits unrestricted use, distribution, and reproduction in any medium, provided the original work is properly cited. In accordance of the Creative Commons Attribution License all Copyrights (C) 2014 are reserved for SCIRP and the owner of the intellectual property Angel Luque et al. All Copyright (C 2014 are guarded by law and by SCIRP as a guardian.

\section{ABSTRACT}

The variation in temperature on the island of Gran Canaria is studied using the method applied to the nearby island of Tenerife [1]. An upward warming trend of $0.09^{\circ} \mathrm{C} \pm 0.05^{\circ} \mathrm{C}(\alpha=0.01)$ was seen from 1946 to date, which has accelerated since the seventies to $0.17^{\circ} \mathrm{C} \pm 0.10^{\circ} \mathrm{C}(\alpha=0.01)$. The increase was higher at night $\left(0.11^{\circ} \mathrm{C} \pm\right.$ $\left.0.05^{\circ} \mathrm{C}\right)$ than by day $\left(0.08^{\circ} \mathrm{C} \pm 0.06^{\circ} \mathrm{C}\right)$, so the temperature range decreased slightly. These values are similar to those of Tenerife and the time series of anomalies for the two islands are highly correlated. On the coast the same relationship to the sea surface temperature was found as in Tenerife, but in the mid-altitude areas to windward, some differences were detected that are hypothetically attributable to the different relief of the two islands.

\section{KEYWORDS}

\section{Global Warming; Canary Islands; Gran Canaria; Temperature Trends; Climatic Change}

\section{Introduction}

The climate change affecting the planet is also evident in the Macaronesian archipelagos. Studies of the Azores, Madeira, Cape Verde and the Canary Islands and its marine environment [1-5] provide evidence of this, focusing on how temperature has varied over the last century and the present one. The region shares an upward tendency, which has become stronger since the mid-seventies.

Studies of trends in land temperatures in the Canary Islands have focused on the island of Tenerife $[1,2,6]$ and show a warming consistent with the estimate for the Northern Hemisphere, if we take into account the geographical location of the Canaries and the tempering effect of the ocean. According to Martín et al. (2012) [1], the temperature on Tenerife increased since 1944 at a rate of $0.09^{\circ} \mathrm{C} \pm 0.04^{\circ} \mathrm{C} /$ decade and since 1970 this has

${ }^{*}$ Corresponding author. accelerated to $0.17^{\circ} \mathrm{C} \pm 0.04^{\circ} \mathrm{C} /$ decade. Warming was greater in the minima than the maxima, and on the summit above $2000 \mathrm{~m}$ a.s.l., it was greater than on the rest of the island, and also in the windward mid-altitude areas exposed to the prevailing winds, than similar leeward areas. The global circulation may exert greater influence on the warming in the high mountains [7] and the sea temperature on the coast air temperature [8], while in the windward mid-altitude areas the main factor is the local effect of the trade winds [1] and heated air invasions from Sahara during dust outbreak events $[9,10]$. Trends in sea surface temperature (SST) also show that warming of the sea surrounding the archipelago is higher as we move southward [4].

The circumstances of each island, and its location in the longitudinal/latitudinal gradient of SST, altitude or terrain, etc., could lead to changes in the magnitude of the trends, so it is interesting to see whether the pattern 
observed for Tenerife applies to neighbouring islands. Gran Canaria is the only one besides Tenerife that has a network of weather stations dense enough to assess its warming. From the geomorphological point of view, it does not reach such a high altitude as Tenerife and its relief is somewhat different. However, it is equally mountainous and also has a pyramidal structure, making it suitable for comparison purposes. Our general aim was therefore to analyse the temperature on this island in order to compare the results with data from Tenerife. For this purpose we have to: 1) accurately calculate annual and monthly trends in overall temperature on Gran Canaria, considering the unique relief of the island, and 2) determine how these trends are distributed locally and may be affected by the orientation (aspect) of the slopes and the warming of the sea surface.

\section{Gran Canaria}

The Canary Islands are located in the southeastern sector of the North Atlantic, roughly between $27^{\circ}$ to $29^{\circ} \mathrm{N}$ and $14^{\circ}$ to $18^{\circ} \mathrm{W}$ (Figure 1 ) They are very close to the African continent, with a very different climate than would be expected at their latitude, thanks to the powerful influence of the dominant northeast trade winds associated with the Azores High Pressure Area [11,12] and the cold
Canary Current. The archipelago consists of seven major islands, Gran Canaria and Tenerife occupying central positions.

Gran Canaria $\left(27.7^{\circ}-28.2^{\circ} \mathrm{N}, 15.3^{\circ}-15.9^{\circ} \mathrm{W}\right)$ with its $1948 \mathrm{~m}$ summit is the third highest of the Canaries. It is located southeast of Tenerife, having an area of $1560 \mathrm{~km}^{2}$ and often a very steep relief. Climatically the north, exposed to the trade winds, is wetter than the south, to leeward, particularly at mid-altitudes where the influence of such winds frequently leads to a stratocumulus layer known locally as the "sea of clouds", typically varying between 800 and $1600 \mathrm{~m}$ a.s.l. in height. The ceiling of these clouds is defined by a temperature inversion layer which is seasonally variable in altitude and thickness $[11,13]$. The cloud bank normally lies at between 1200 and 1600 $\mathrm{m}$ but in the months of July and August often descends to 800 - $1000 \mathrm{~m}$ [14]. This vertical structure of the troposphere only disappears under unstable air currents or occasionally on days with advections of air masses from the nearby Sahara.

\section{Methodology}

To measure the warming in Gran Canaria we tried to cover the widest climatic diversity and optimize the data quality using a specific statistical treatment focused on

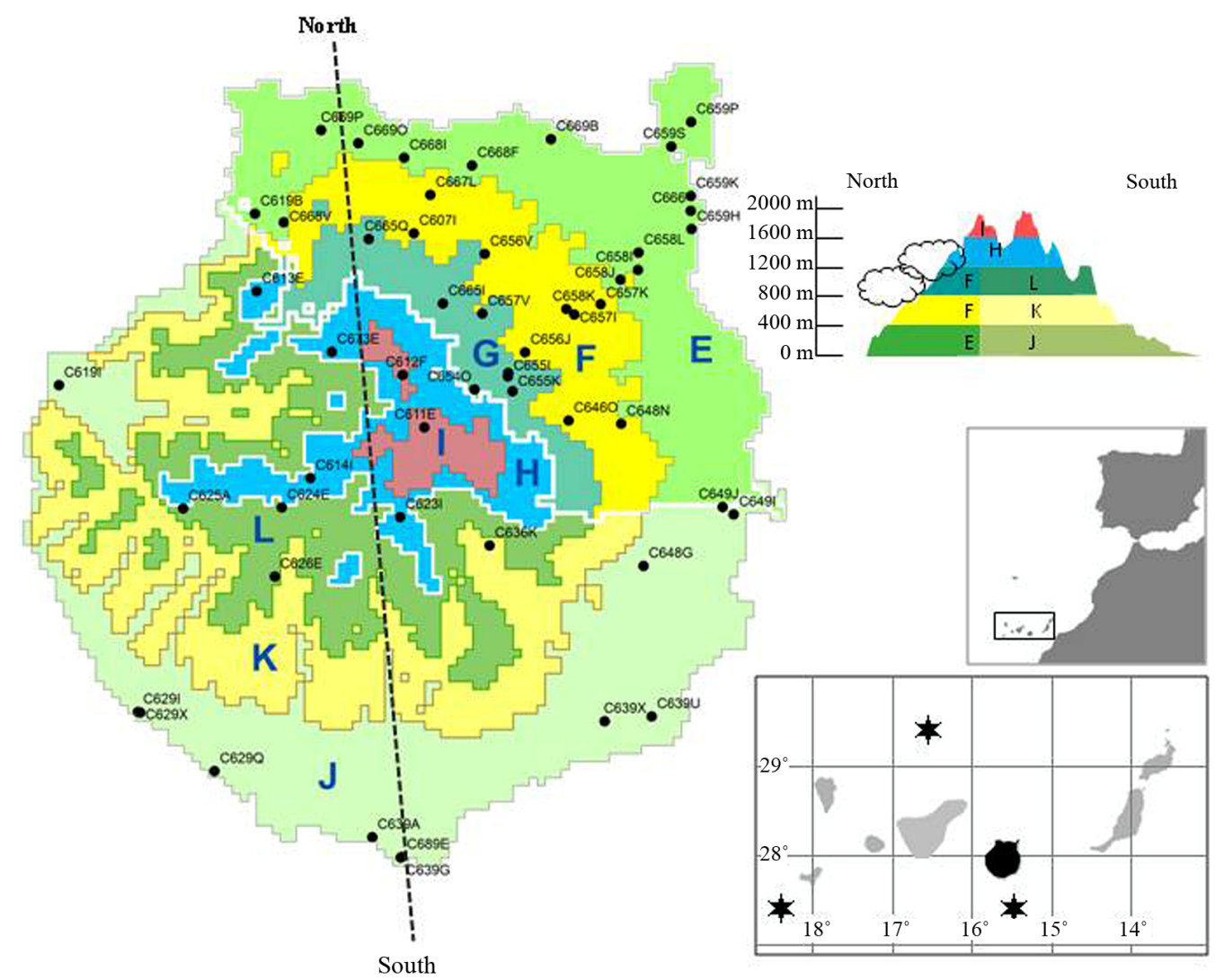

Figure 1. Distribution of temperature stations considered in this analysis. Source areas of the SST data are indicated by stars on the map of the Canary Islands. 
detecting trends. After analysis of the temperature series based on their location, altitude and orientation, length and complementarity between stations, we selected the 26 weather stations in Table 1 . They are all managed by the State Meteorological Agency (AEMET).

Although the baseline data were daily readings, for the purposes of this study they were grouped into monthly series of maxima and minima. These were corrected for anomalous values (outliers), gaps were filled and inhomogeneities adjusted. For this we used the Standard Normal Homogeneity Test (SNHT) $[15,16]$ and the Pettitt test [17], according to the methodology detailed in
Martín et al. (2012) [1]. The annual series were obtained from the average of the monthly series. The trend was obtained from climate anomalies derived from differential temperatures relative to the baseline period 19701999. For all series of anomalies, the linear regression and level of significance were calculated according to Spearmann's rank test [18]. The data from various stations were grouped by averaging and adjustment of variances after the approach developed by Osborn et al. (1997) [19] and the statistical significance of linear trends was assessed, accounting for temporal autocorrelation following the method of Santer et al. (2000) [20].

Table 1. Source stations of the temperature series. In black: those used to construct the reference series, in red: data used to correct anomalies and fill gaps. The filled squares indicate years in which data are available 12 months a year.

\begin{tabular}{|c|c|c|c|c|c|c|c|c|}
\hline & Station & $1944-50$ & $1951-1960$ & $1961-1970$ & 1971-1980 & $1991-2$ & 00 & $001-2010$ \\
\hline \multirow[t]{9}{*}{ E } & C619B (3) & & & & 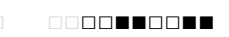 & 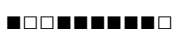 & 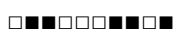 & 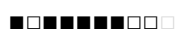 \\
\hline & C669P (6) & 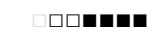 & 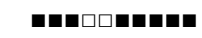 & 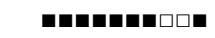 & 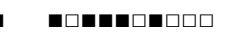 & 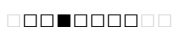 & & \\
\hline & C6690 (7) & & & 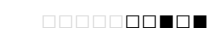 & 口иव & 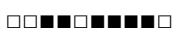 & 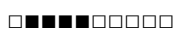 & \\
\hline & C659P (17) & & 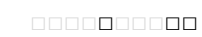 & 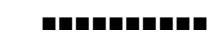 & 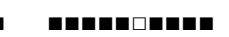 & 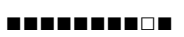 & 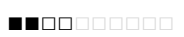 & \\
\hline & C668V (2) & & & & & 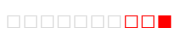 & 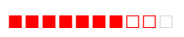 & 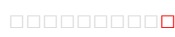 \\
\hline & C658L (12) & & & & & & 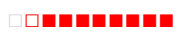 & mघmmambu \\
\hline & C658J (14) & & & & & 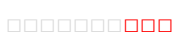 & 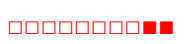 & 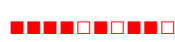 \\
\hline & C658I (15) & & 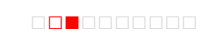 & 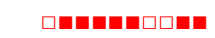 & 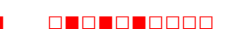 & 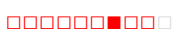 & & \\
\hline & C659K (16) & & & 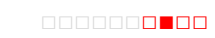 & 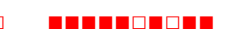 & 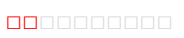 & & \\
\hline \multirow[t]{3}{*}{$\mathrm{F}$} & C658K (36) & & & & 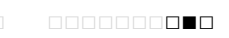 & 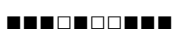 & 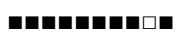 & g日emgengu \\
\hline & C656J (37) & & & & & & 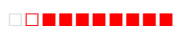 & 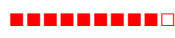 \\
\hline & C646O (47) & & & & & & 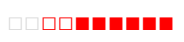 & gengemenge \\
\hline \multirow[t]{4}{*}{$\mathrm{G}$} & C665Q (8) & & & & 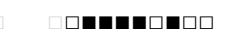 & ㅁ & ロ & \\
\hline & C665I (46) & 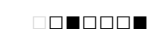 & 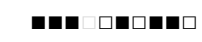 & 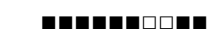 & 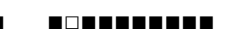 & 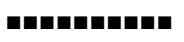 & 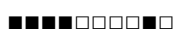 & 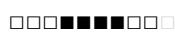 \\
\hline & C655K (30) & & & & & 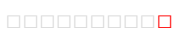 & 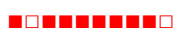 & 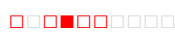 \\
\hline & C655Q (31) & & & & & 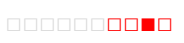 & 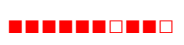 & 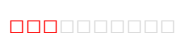 \\
\hline \multirow[t]{3}{*}{$\mathrm{H}$} & C613E (1) & & 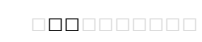 & 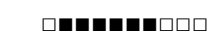 & 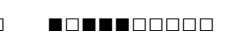 & 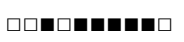 & 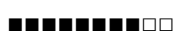 & 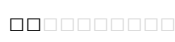 \\
\hline & C623I (28) & & 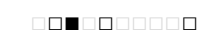 & 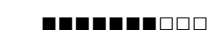 & 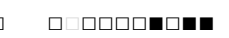 & 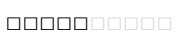 & 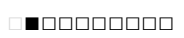 & ㅁำm \\
\hline & C614I (40) & & 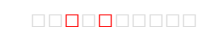 & 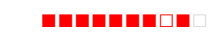 & 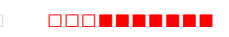 & 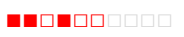 & 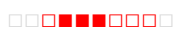 & \\
\hline \multirow[t]{3}{*}{$\mathrm{J}$} & C649I (42) & & 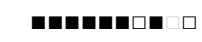 & 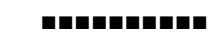 & 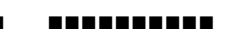 & 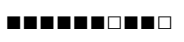 & 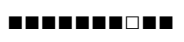 & gmamamgun \\
\hline & C629I (21) & & & & & 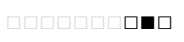 & 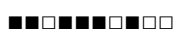 & 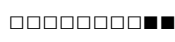 \\
\hline & C689E (29) & & & & & & 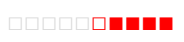 & 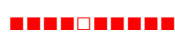 \\
\hline \multirow[t]{2}{*}{$\mathrm{L}$} & C624E (41) & & 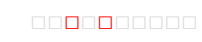 & 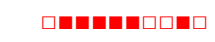 & 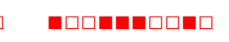 & 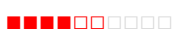 & 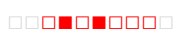 & \\
\hline & C625A (19) & & घா & 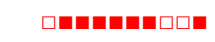 & 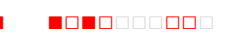 & & & \\
\hline & Series-E & 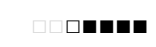 & 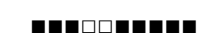 & gmamengen & 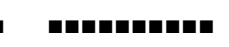 & 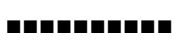 & 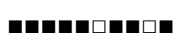 & 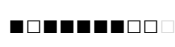 \\
\hline & Series-F & & & & 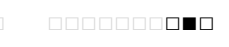 & 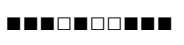 & 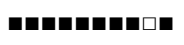 & 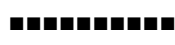 \\
\hline & Series-G & 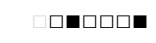 & घต & 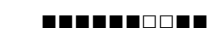 & 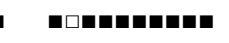 & 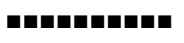 & $\mathbf{m} \mathbf{m} \square \square \square \square \mathbf{m}$ & 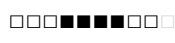 \\
\hline & Series-H & & $\square$ घ & 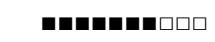 & 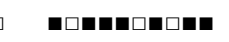 & 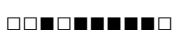 & 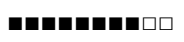 & 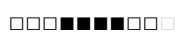 \\
\hline & Series-J & & 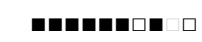 & gengerege & gengenger & 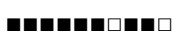 & Gmengerge & gengemeng \\
\hline & ries-EFGHJ & 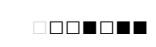 & 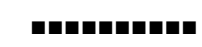 & gumergeng & 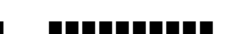 & 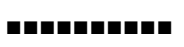 & 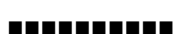 & $\mathbf{m} \mathbf{m}$ \\
\hline
\end{tabular}




\section{Meteorological Stations}

The weather stations used are distributed geographically by areas as shown in Figure 1. Only 11 of the 26 stations were utilized, the others served as support in the gapfilling or correction processes (Table 1). To construct reference series, stations were grouped by similar altitude and orientation, taking orography (i.e. relief) into account. We identified three sectors on the windward northeast slope, another three to the southwest (leeward) and two in the high mountain zone. Several sectors were also grouped together to form reference series, for which the anomalies obtained by averaging among sectors were weighted according to their surface areas (E: $285.8 \mathrm{~km}^{2}$, F: $168.8 \mathrm{~km}^{2}$; G: $95.8 \mathrm{~km}^{2}, \mathrm{H}: 132 \mathrm{~km}^{2}, \mathrm{~J}: 396.2 \mathrm{~km}^{2}$; K: $291.5 \mathrm{~km}^{2}$, and L: $225.2 \mathrm{~km}^{2}$ ) (Figure 1).

The series from the stations in the sectors between 400 $\mathrm{m}$ and $1200 \mathrm{~m}$ a.s.l. on the southwest (SW) slope (sectors $\mathrm{K}$ and $\mathrm{L}$ in Figure 1) were too short to allow trend analysis, so they were only used as support in adjusting the other stations. The longer station series ranged from the mid-1940s in two cases (sector E between 0 and 400 $\mathrm{m} \mathrm{NE}$, and sector $\mathrm{G}$ between 800 and $1200 \mathrm{~m} \mathrm{NE}$ ), the beginning of the 50s in one (sector J between 0 and 400 $\mathrm{m} \mathrm{SW}$ ), the early sixties in another (sector H. mountain zone between 1200 and 1600) and the late seventies in the last (sector $F$ between 400 and $800 \mathrm{~m} \mathrm{NE}$ ).

The vertical section of the island in Figure 1 shows the altitudinal belts each corresponding to $400 \mathrm{~m}$ of height, which also identifies the sectors in the study. The temperature series of the different stations analysed had widely variable lengths and frequent breaks (Table 1).

However the groupings performed within the same altitudinal belt provided higher quality series. When data from different belts were pooled into reference series due to similar orientation and/or altitude, further improved quality and longer series were achieved. These in almost all cases stretched from 1946 to 2010 .
The series from each individual sector were obtained from the simple average and adjustment of variances for the stations included in them. Those combining several sectors resulted from the average weighted as a function of the surface area of each sector and the variance adjustment. The windward reference series was built up from the series $\mathrm{E}$ and $\mathrm{F}$, the leeward solely from $\mathrm{J}$, the high mountain series $\mathrm{G}$ and $\mathrm{H}$, and finally the reference series for the whole island was obtained from E, F, G, H and $\mathrm{J}$.

\section{Results}

596 monthly values were added in the 312 series of maximum temperatures (26 stations $\times 12$ months) and 432 minima, taking as reference the best correlated monthly series. Most of these additions were made in the November and December maxima and the February and March minima. Jump inhomogeneities were detected in 59 series of maxima and 78 of minima from the 11 stations used for obtaining the final reference series.

Inhomogeneities were detected in all months in both the maxima and minima, but especially in the maxima of March, June and December. Stations in the reference zone of sector E (0 - $400 \mathrm{~m}$ a.s.l., $\mathrm{N})$ had the highest number of inhomogeneities. A relative homogenization was undertaken in the series C658K (Santa Brigida municipality, sector F), based on previously homogenized stretches of the data from C649I (Gando, Las Palmas airport).

The series of anomalies with respect to the 1970-1999 baseline period of mean temperature for the island showed an upward growth trend of $0.09^{\circ} \mathrm{C} \pm 0.05^{\circ} \mathrm{C}(\alpha=0.05)$ per decade between 1946 and 2010 (Table 2). This trend was even more pronounced in $1970-2010\left(0.17^{\circ} \mathrm{C} \pm\right.$ $0.10^{\circ} \mathrm{C} /$ decade) (Figure 2), similar to that obtained for the neighbouring island of Tenerife in the same periods [1].

Maxima and minima behaved asymmetrically (Figure

Table 2. Decadal rate of warming in annual temperature series $\left({ }^{*} \alpha=0.01 ;{ }^{* *} \alpha=0.05\right.$, ns not signif.).

\begin{tabular}{|c|c|c|c|c|c|}
\hline & & $\mathrm{T}_{\mathrm{ave}}$ & $\mathrm{T}_{\max }$ & $\mathrm{T}_{\min }$ & DTR \\
\hline Whole island & ${ }^{\circ} \mathrm{C} /$ decade $_{(1946-2010)}$ & $\begin{array}{c}0.09 \pm 0.05^{*} \\
r^{2}: 0.16\end{array}$ & $\begin{array}{c}0.06 \pm 0.06^{*} \\
r^{2}: 0.06\end{array}$ & $\begin{array}{c}0.12 \pm 0.07^{*} \\
r^{2}: 0.28\end{array}$ & n.s. \\
\hline Series $\mathrm{E}+\mathrm{F}+\mathrm{G}+\mathrm{H}+\mathrm{J}$ & ${ }^{\circ} \mathrm{C} /$ decade $_{(1970-2010)}$ & $\begin{array}{c}0.17 \pm 0.10^{*} \\
r^{2}: 0.23\end{array}$ & $\begin{array}{c}0.17 \pm 0.12^{*} \\
\mathrm{r}^{2}: 0.17\end{array}$ & $\begin{array}{c}0.17 \pm 0.13^{*} \\
r^{2}: 0.28\end{array}$ & n.s. \\
\hline Windward & ${ }^{\circ} \mathrm{C} / \mathrm{decade}_{(1946-2010)}$ & $\begin{array}{c}0.08 \pm 0.05^{* *} \\
r^{2}: 0.17\end{array}$ & $\begin{array}{c}0.11 \pm 0.08^{* *} \\
r^{2}: 0.19\end{array}$ & n.s. & n.s. \\
\hline Series E $+F$ & ${ }^{\circ} \mathrm{C} /$ decade $_{(1970-2010)}$ & $\begin{array}{c}0.10 \pm 0.10^{* *} \\
r^{2}: 0.09\end{array}$ & $\begin{array}{c}0.12 \pm 0.12^{* *} \\
r^{2}: 0.09\end{array}$ & n.s. & n.s. \\
\hline $\begin{array}{c}\text { Leeward } \\
\text { Series J }\end{array}$ & $\begin{array}{l}{ }^{\circ} \mathrm{C} / \text { decade }_{(1951-2010)} \\
{ }^{\circ} \mathrm{C} / \text { decade }_{(1970-2010)}\end{array}$ & $\begin{array}{c}0.11 \pm 0.09^{* *} \\
r^{2}: 0.18 \\
0.21 \pm 0.19^{* *} \\
r^{2}: 0.29\end{array}$ & $\begin{array}{c}\text { n.s. } \\
0.26 \pm 0.21^{* *} \\
r^{2}: 0.36\end{array}$ & $\begin{array}{c}0.14 \pm 0.09^{*} \\
r^{2}: 0.25 \\
\text { n.s. }\end{array}$ & n.s. \\
\hline Mountain & ${ }^{\circ} \mathrm{C} /$ decade $_{(1946-2008)}$ & n.s. & n.s. & $\begin{array}{c}0.18 \pm 0.15^{*} \\
0.20\end{array}$ & n.s. \\
\hline Series $\mathrm{G}+\mathrm{H}$ & ${ }^{\circ} \mathrm{C} /$ decade $_{(1970-2008)}$ & $\begin{array}{c}0.16 \pm 0.16^{* *} \\
r^{2}: 0.10\end{array}$ & n.s. & $\begin{array}{c}0.31 \pm 0.30^{* *} \\
r^{2}: 0.23\end{array}$ & n.s. \\
\hline
\end{tabular}


A) Mean temperature

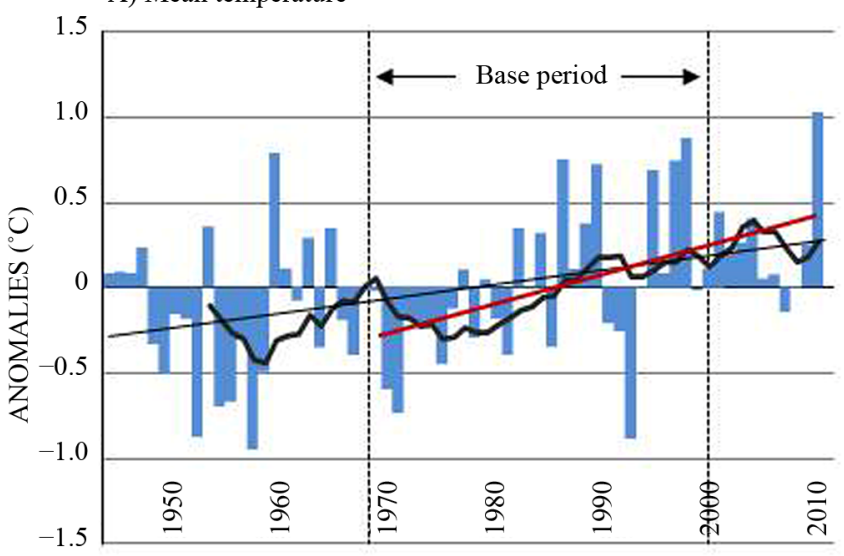

A) Maximum temperature

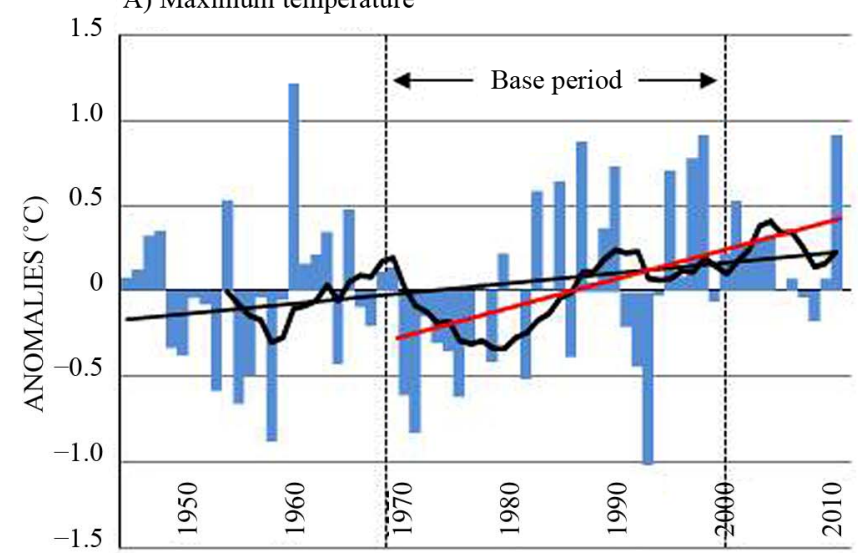

A) Minimum temperature

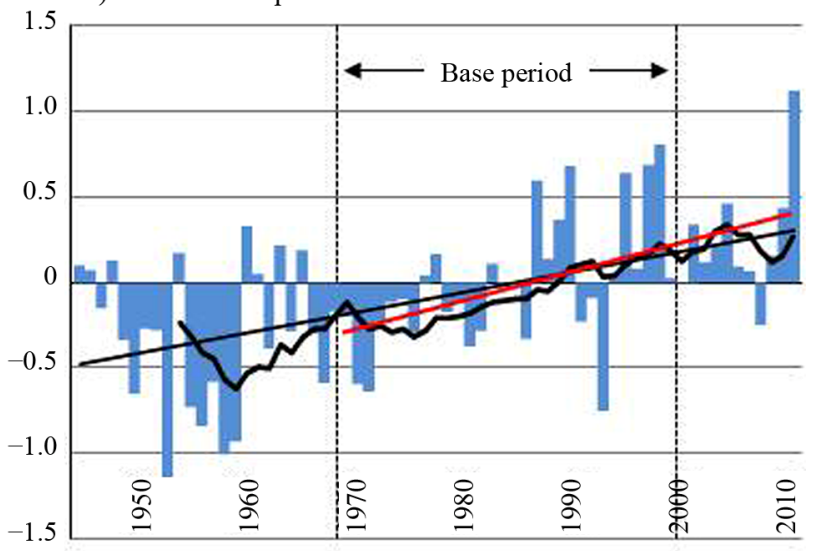

A) Diurnal Temperature Range (DTR)

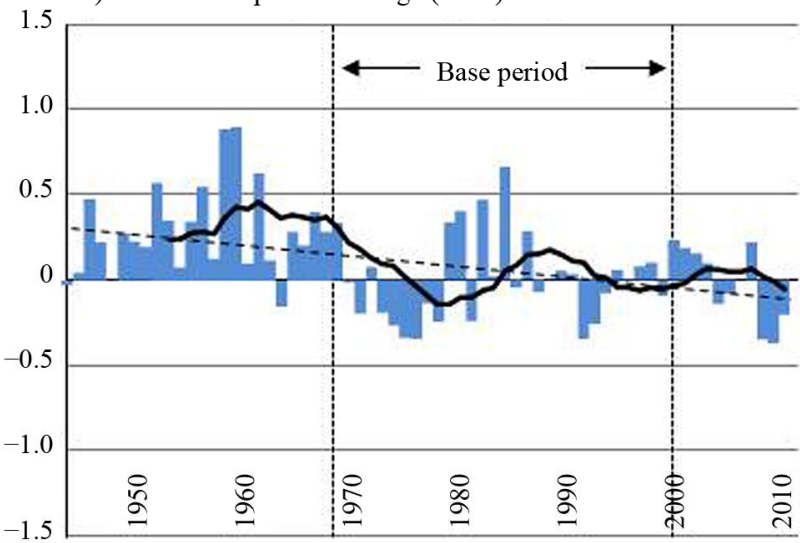

Figure 2. Graph of anomalies in mean, maximum, and minimum temperature and the monthly mean daily temperature range (DTR) from the overall reference series for the island. The dashed line indicates a nonsignificant trend.

2). While the maxima showed a mild increase between 1946 and $2010\left(0.06^{\circ} \mathrm{C} \pm 0.06^{\circ} \mathrm{C} /\right.$ decade $)$, the minima rose more $\left(0.12^{\circ} \mathrm{C} \pm 0.07^{\circ} \mathrm{C}\right.$ per decade $(\alpha=0.05)$. This increase was almost steady over time and was interrupted only by a slight cooling in the seventies. The last four decades saw a parallel similar acceleration of $0.17^{\circ} \mathrm{C} /$ decade. The difference in the average minima over the latest thirty years (1981-2010) and the earliest thirty (1946-1975) was $0.45^{\circ} \mathrm{C} \pm 0.27^{\circ} \mathrm{C}$, but the standard deviation was practically the same, showing similar climate variability in both periods.

The trends in average temperature were different in the mountain sectors $(\mathrm{G}+\mathrm{H})$ and near the coast (Table 2). In the latter, the warming measured since the mid $20^{\text {th }}$ century was greater to leeward (sector $\mathrm{J}$ ) than windward (sectors $\mathrm{E}+\mathrm{F})$. In mountain areas $(\mathrm{G}+\mathrm{H})$ a significant trend was only found from 1970 on, so comparisons with the coastal areas are limited to this period, in which warming was greater to leeward $\left(0.21^{\circ} \mathrm{C} \pm 0.19^{\circ} \mathrm{C} /\right.$ decade $)$ and mountains $\left(0.16^{\circ} \mathrm{C} \pm 0.16^{\circ} \mathrm{C} /\right.$ decade $)$, in that order, than in the windward coastal sector $\left(0.10^{\circ} \mathrm{C} \pm 0.10^{\circ} \mathrm{C} /\right.$ decade).
The temperature on land has an annual cycle with its highest values in August and lowest in January. The monthly temperature evolution shows a mild warming for the whole island (Table 3), most noticeable at the beginning of spring (March), in October and especially in December $\left(0.13^{\circ} \mathrm{C} \pm 0.09^{\circ} \mathrm{C} /\right.$ decade $)$. The maxima only show significant trends in June and principally in December $\left(0.16^{\circ} \mathrm{C} \pm 0.12^{\circ} \mathrm{C} /\right.$ decade $)$, while the minima rise every month, but especially in March $\left(0.18^{\circ} \mathrm{C} \pm 0.11^{\circ} \mathrm{C} /\right.$ decade) and October $\left(0.15^{\circ} \mathrm{C} \pm 0.08^{\circ} \mathrm{C} /\right.$ decade $)$. The increase in the máxima of December could be related to the intrusion of warm air from North Africa described by Nakamae \& Shiotani (2013) [10] for the northern winter. The temperature range tended to decrease, although in many months the trend was not statistically significant.

The trend in the SST was derived from data between 1948 and 2010 from the reanalysis of the National Centers for Environmental Prediction (NCEP) and National Center for Atmospheric Research (NCAR) [21] in three areas: one to the north of Gran Canaria (28.5 - $29.5 \mathrm{~N} / 17$ - $16 \mathrm{~W})$, one south (26.5 - 27.5 N/16 - 15 W) and another south-west $(26-27 \mathrm{~N} / 19-18 \mathrm{~W})$. The results indicate 
Table 3. Temperature variation trends on Gran Canaria in ${ }^{\circ} \mathrm{C} /$ decade from the aggregated sectors $\mathrm{E}, \mathrm{F}, \mathrm{G}, \mathrm{H}$ and $\mathrm{J}$, and in the SST around the island $\left({ }^{*} \alpha=0.01{ }^{* *} \alpha=0.05\right.$, n.s. not signif.).

\begin{tabular}{|c|c|c|c|c|c|}
\hline & $\mathrm{TX}$ & $\mathrm{T}_{\max }$ & $\mathrm{T}_{\min }$ & DTR & SST \\
\hline January & $\begin{array}{c}0.08 \pm 0.09^{*} \\
r^{2}: 0.06\end{array}$ & n.s. & $\begin{array}{c}0.10 \pm 0.08^{*} \\
r^{2}: 0.08\end{array}$ & n.s. & $0.12 \pm 0.07^{*}$ \\
\hline February & n.s. & n.s. & $\begin{array}{c}0.12 \pm 0.11^{* *} \\
r^{2}: 0.07\end{array}$ & n.s. & $0.08 \pm 0.07^{*}$ \\
\hline March & $\begin{array}{l}0.11 \pm 0.13^{*} \\
r^{2}: 0.04\end{array}$ & n.s. & $\begin{array}{l}0.18 \pm 0.11^{* *} \\
r^{2}: 0.14\end{array}$ & n.s. & \\
\hline April & $\begin{array}{c}0.10 \pm 0.11^{*} \\
0.05\end{array}$ & n.s. & $\begin{array}{c}0.11 \pm 0.10^{*} \\
r^{2}: 0.07\end{array}$ & n.s. & \\
\hline May & $\begin{array}{c}0.09 \pm 0.10^{*} \\
r^{2}: 0.05\end{array}$ & n.s. & $\begin{array}{c}0.12 \pm 0.09^{* *} \\
\mathrm{r}^{2}: 0.11\end{array}$ & $\begin{array}{c}-0.07 \pm 0.06^{* *} \\
r^{2}: 0.08\end{array}$ & \\
\hline June & $\begin{array}{c}0.09 \pm 0.07^{* *} \\
r^{2}: 0.09\end{array}$ & $\begin{array}{l}0.07 \pm 0.08^{*} \\
r^{2}: 0.06\end{array}$ & $\begin{array}{c}0.10 \pm 0.07^{* *} \\
r^{2}: 0.11\end{array}$ & n.s. & $0.10 \pm 0.07^{*}$ \\
\hline July & n.s. & n.s. & $\begin{array}{c}0.11 \pm 0.08^{* *} \\
r^{2}: 0.10\end{array}$ & $\begin{array}{c}-0.12 \pm 0.08^{* *} \\
r^{2}: 0.14\end{array}$ & $0.08 \pm 0.07^{*}$ \\
\hline August & $\begin{array}{c}0.08 \pm 0.10^{*} \\
0.03\end{array}$ & n.s. & $\begin{array}{c}0.10 \pm 0.09^{*} \\
r^{2}: 0.08\end{array}$ & $\begin{array}{c}-0.12 \pm 0.06^{* *} \\
r^{2}: 0.19\end{array}$ & $0.08 \pm 0.07^{*}$ \\
\hline September & n.s. & n.s. & $\begin{array}{c}0.11 \pm 0.00^{* *} \\
r^{2}: 0.10\end{array}$ & $\begin{array}{c}-0.09 \pm 0.06^{* *} \\
r^{2}: 0.12\end{array}$ & $0.11 \pm 0.07^{*}$ \\
\hline October & $\begin{array}{c}0.11 \pm 0.10^{*} \\
r^{2}: 0.06\end{array}$ & n.s. & $\begin{array}{c}0.15 \pm 0.00^{* *} \\
r^{2}: 0.18\end{array}$ & n.s. & $0.16 \pm 0.07^{*}$ \\
\hline November & $\begin{array}{c}0.08 \pm 0.10^{*} \\
r^{2}: 0.04\end{array}$ & n.s. & $\begin{array}{c}0.10 \pm 0.08^{* *} \\
r^{2}: 0.11\end{array}$ & n.s. & $0.18 \pm 0.07^{*}$ \\
\hline December & $\begin{array}{c}0.13 \pm 0.09^{* *} \\
r^{2}: 0.11\end{array}$ & $\begin{array}{c}0.16 \pm 0.12^{* *} \\
r^{2}: 0.10\end{array}$ & $\begin{array}{c}0.10 \pm 0.07^{*} \\
r^{2}: 0.11\end{array}$ & n.s. & $0.17 \pm 0.07^{*}$ \\
\hline
\end{tabular}

that the sea temperature followed an annual cycle characterized by its movement with respect to land in one or two months, due to the thermal inertia associated with the different specific heat of oceanic and continental surfaces. Thus the highest temperature occurs in September or October, and the lowest in February-March. The trend from 1948 to 2010 showed a faster warming in the months of September to January, especially in October, November and December. In these three months, along with January and February, the SST during 1970-1999 was equal to or greater than the average temperature in the same period on land in sector $\mathrm{J}$ (coast).

\section{Analysis and Discussion}

Since 1946, both Gran Canaria and Tenerife had seven of their ten warmest years in the two latest decades and seven of the ten coldest years in the two earliest decades. The warmest year on both islands was 2010. Gran Canaria showed a warming pattern similar to Tenerife, as shown by the high correlation between the annual and monthly series of the two islands $(\geq 0.8)$ and the similarities in the temporal variations. Both had a mild warming in the sixties and a cooling in the seventies, and thereafter another temperature rise that has gradually accelerated up to the present. Global models generally show greater warming in the early forties followed by a gentler one in the sixties $[22,23]$, but the data set analysed in the Canaries does not reach back so early. In addition, max- ima and minima in the two islands showed asymmetric behaviour with a greater increase in nighttime temperatures, coinciding with the observed worldwide trends [24].

The cooling in the seventies coincides with reduction in received solar radiation and resultant global dimming through excess sulphur emissions, and has been described on a global scale $[25,26]$ and in the Canary Islands [2]. Similarly the warming in the eighties reflects a worldwide pattern associated with an increase in atmospheric transparency [27], also found in the Canaries [2]. Precisely this pattern supports the hypothesis that the current warming could be greater than the apparent, as it seems to be cushioned by a certain amount of cooling due to atmospheric pollution [28,29]. Finally, there was also a slight chill in the early nineties, coinciding with falling temperatures in tropical and subtropical zones of the planet due to the eruption of Mt. Pinatubo [30] (McCormick et al., 1995).

Despite these correspondences between the temperature records of Tenerife and Gran Canaria, there are also differences such as the dissimilar temperature behaviour on the windward slopes of the two islands. Regarding Tenerife, it was postulated that warming at between 400 and $800 \mathrm{~m}$ above sea level (sector F) was augmented by an increase in cloud cover preventing nocturnal infrared radiation escaping into the atmosphere, thus raising the average value of the minima [1], and a similar situation has been observed in other mountainous islands like Cy- 
prus [31]. Marzol has shown empirically in Tenerife that the windward fogs caused by the trade winds are more frequent at night than day [13,32]. Although probably also the case on Gran Canaria, the lack of measurements of cloudiness in the mid-altitude areas of this island hinders confirmation of this; we can only extrapolate from the temperature behaviour in each sector.

Sectors E + F of Gran Canaria showed no asymmetry between minima and maxima like that observed in Tenerife for the corresponding area, while the band formed by sectors $\mathrm{G}+\mathrm{H}$ at higher altitudes displayed similar behaviour of the minima to " $\mathrm{E}+\mathrm{F}$ " of Tenerife, at lower altitudes. It seems that the $\mathrm{G}+\mathrm{H}$ band of Gran Canaria behaves similarly to $\mathrm{E}+\mathrm{F}$ of Tenerife in terms of day/ night temperature asymmetry. The lack of data for Tenerife prevents comparing the $\mathrm{G}+\mathrm{H}$ sectors of the two islands, but we can venture that this altitudinal mismatch is caused by the different relief of the islands, since the windward slopes of Gran Canaria generally have a gentler gradient than those of Tenerife (Figure 3). If the stratocumulus layer were confined to the proximity of the slopes, coastal sectors (E, F) could be outside the cloud coverage or at least under a thinner cloudbank, less effective in stopping infrared radiation. The stratocumulus would surround and cover sectors further inland such as $\mathrm{G}$ and $\mathrm{H}$ (Figure 3). Furthermore, the windward sectors in Tenerife are well defined by the relief, while they are much more diffuse toward the south on the eastern coast of Gran Canaria and to the west on the northern coast. The importance of local topography delimitation of areas affected by the fog has already been pointed out by sev- eral authors $[13,33]$.

Jin-Jia et al. (2011) [34] argue that the SST plays a key role in global warming, so it could function as a regulator of land temperatures. Numerous publications confirm the warming of the ocean surfaces, and specifically the North Atlantic [35]. This heat increase in the SST should be reflected on land, especially in coastal areas. Indeed, Martín et al. (2012) [1] showed that the nearer the land sectors of Tenerife are to the coast, the closer their warming was to that of the sea surface. For Gran Canaria, a good correlation was obtained $(\geq 0.8)$ between the SST for the months of November, December and January taken together, and the average temperature of the same months for sector $\mathrm{J}$ on land, and also with the six months of greatest warming in the sea. This clearly shows the relationship between the sea-surface and land temperatures. The warming trend in sector $\mathrm{J}$ of $\mathrm{Gran} \mathrm{Ca}$ naria was slightly higher $\left(0.11^{\circ} \mathrm{C} \pm 0.09^{\circ} \mathrm{C} / \mathrm{dec}\right.$ ade $)$ in the sector $\mathrm{J}$ of Tenerife $\left(0.09^{\circ} \mathrm{C} \pm 0.05^{\circ} \mathrm{C} /\right.$ decade $)$, which may be associated with its more southerly position. As Santos et al. (2012) [4] demonstrated, the upward thermal trend in the SST increases southward in the region.

\section{Conclusion}

Our study corroborates for Gran Canaria the warming observed previously on Tenerife, reinforcing the measurements made in this area of the Atlantic for the column of the lower troposphere from the coast to the high mountain zone around $2000 \mathrm{~m}$ a.s.l. Despite orographic differences between the two islands, the temperature

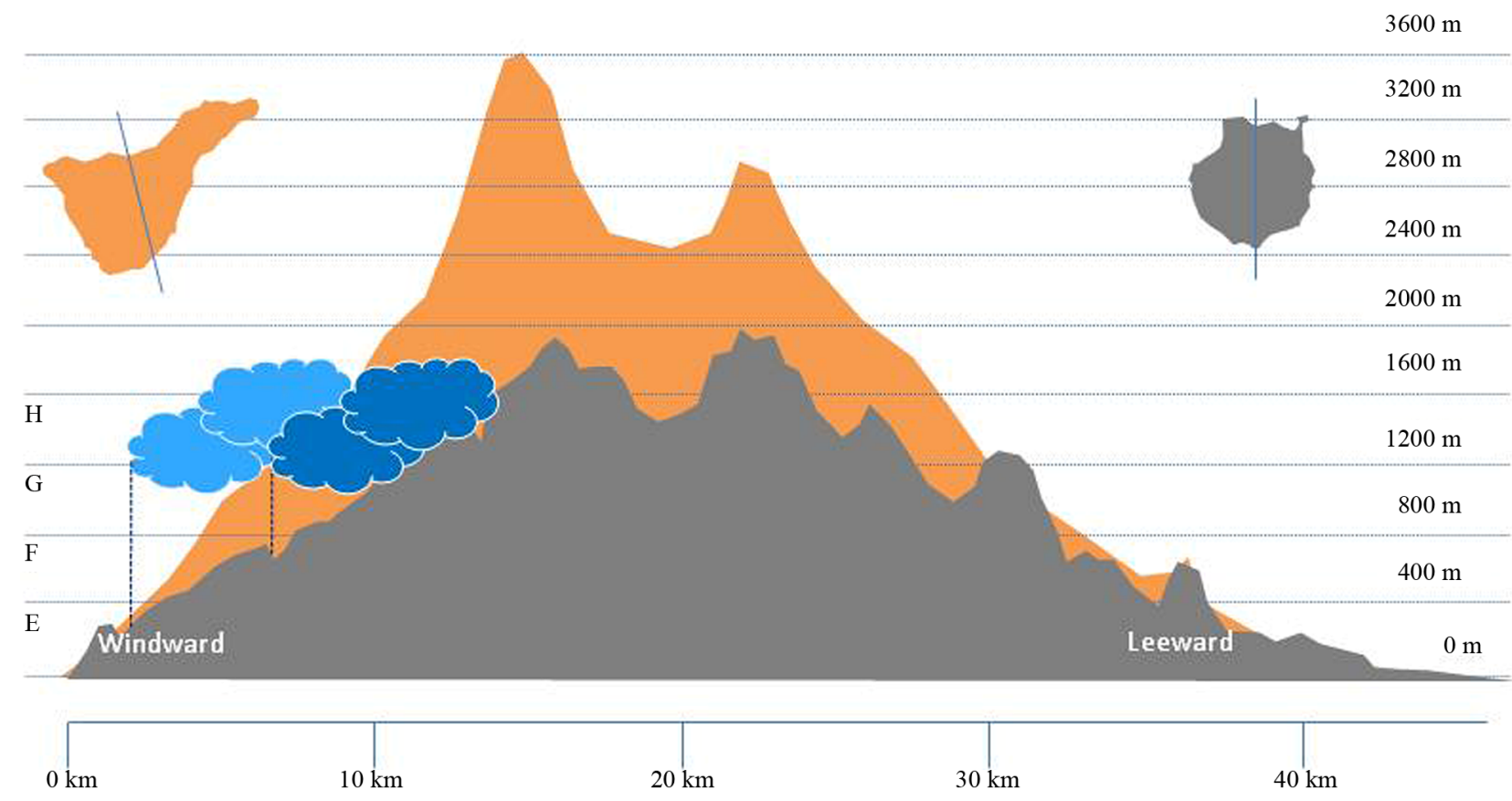

Figure 3. Silhouettes to scale of Tenerife and Gran Canaria, following the transects indicated, and hypothetical representation of the respective areas under the trade-wind clouds. 
trend reflects both the high and low temperatures typical of global climate variations and maintains a similar upward trend in line with the rest of the world. This in turn contributes additional soundness to the statistical results. The hypothesis of the role of clouds in middle altitude warming on windward slopes observed in Tenerife could not be confirmed for Gran Canaria. It can however be argued that the difference derives from the islands' contrasting relief and its relationship with the stratocumulus layer. Finally, changes in the land temperature near the coast were well correlated with sea temperature.

\section{Acknowledgements}

The analyses in this study were funded by the project Clima-Impacto MAC/3/C159 of the transnational cooperation programme MAC 2007-2013, led by the Department of the Environment of the Canary Islands Government, with participation of the Ministry of the Environment, Rural Development and Marine Resources of Cape Verde as member. The authors are specifically grateful to the State Meteorological Agency (AEMET) for the provision of basic climatic information from Weather Stations on Gran Canaria, thanks to a collaboration agreement between the Agency and the Government of the Canary Islands.

\section{REFERENCES}

[1] J. L. Martín, J. Bethencourt and E. Cuevas-Agulló, “Assessment of Global Warming on the Island of Tenerife, Canary Islands (Spain). Trends in Minimum, Maximum and Mean Temperatures since 1944," Climatic Change, Vol. 114, No. 2, 2012, pp. 343-355.

http://dx.doi.org/10.1007/s10584-012-0407-7

[2] E. Sanroma, E. Palle and A. Sánchez-Lorenzo, "LongTerm Changes in Insolation and Temperatures at Different Altitudes," Environmental Research Letters, Vol. 5, No. 2, 2010, pp. 1-6. http://dx.doi.org/10.1088/1748-9326/5/2/024006

[3] F. D. Santos, M. A. Valente, E. B. Azevedo, A. R. Tomé and F. Coelho, "Climate Change Scenarios in the Azores and Madeira Islands," World Resource Review, Vol. 16, No. 4, 2004, pp. 473-491.

[4] F. Santos, M. de Castro, M. Gómez-Gesteira and I. Alvarez, "Differential in Coastal and Oceanic SST Warming Rates along the Canary Upwelling Ecosystems from 1982 to 2010," Continental Shelf Research, Vol. 47, 2012, pp. 1-6. http://dx.doi.org/10.1016/j.csr.2012.07.023

[5] T. E. Cropper and E. Hanna, "An Analysis of the Climate of Macaronesia, 1865-2012," International Journal of Climatology, 2013. http://onlinelibrary.wiley.com/doi/10.1002/joc.3710/pdf http://dx.doi.org/10.1002/joc.3710

[6] J. J. Oñate and A. Pou, "Temperature Variations in Spain since 1901: A Preliminary Analysis," International Journal of Climatology, Vol. 16, No. 7, 1996, pp. 805-815.
http://dx.doi.org/10.1002/(SICI)1097-0088(199607)16:7< 805::AID-JOC48>3.0.CO;2-Z

[7] E. Andrews, J. A. Ogren, P. Bonasoni, P. Marinoni, E. Cuevas, S. Rodríguez, J. Y. Sun, D. A. Jaffe, E. V. Fischer, U. Baltenperger, E. Weingartner, M. Collaud, M. Coen, S. Sharma, A. M. Macdonald, W. R. Leaitch, N. H. Lin, T. Arsov, I. Kalapov, A. Jefferson and P. Sheridan, "Climatology of Aerosol Radiative Properties in the Free Troposphere," Atmospheric Research, Vol. 102, No. 4, 2011, pp. 365-393.

http://dx.doi.org/10.1016/j.atmosres.2011.08.017

[8] C. Deser, A. S. Phillips and M. A. Alexander, "Twentieth Century Tropical Sea Surface Temperature Trends Revisited," Geophysical Research Letters, Vol. 37, No. 10, 2010. http://dx.doi.org/10.1029/2010GL043321

[9] S. Alonso-Pérez, E. Cuevas, C. Pérez, X. Querol, J. M. Baldasano, R. Draxler and J. J. de Bustos, "Trend Changes of African Airmass Intrusions in the Marine Boundary Layer over the Subtropical Eastern North Atlantic Region in Winter," Tellus B, Vol. 63, No. 2, 2011, pp. 255-265.

http://dx.doi.org/10.1111/j.1600-0889.2010.00524.x

[10] K. Nakamae and M. Shiotani, "Interannual Variability in Saharan Dust over the North Atlantic Ocean and Its Relation to Meteorological Fields during Northern Winter," Atmospheric Research, Vol. 120, 2013, pp. 336-346 http://dx.doi.org/10.1016/j.atmosres.2012.09.012

[11] I. Font, "El Tiempo Atmosférico en las Islas Canarias," Servicio Meteorológico Nacional, Serie A (Memoria No. 26), Madrid, 1956.

[12] M. V. Marzol, "El Clima,” In: J. M. Fernández-Palacios and J. L. Martín-Esquivel, Eds., Naturaleza de las Islas Canarias. Ecología y Conservación, Publicaciones Turquesa, Santa Cruz de Tenerife, 2001, pp. 87-93.

[13] M. V. Marzol, "Temporal Characteristics and Fog Water Collection during Summer in Tenerife (Canary Islands, Spain)," Atmospheric Research, Vol. 87, No. 3-4, 2008 , pp. 352-361.

http://dx.doi.org/10.1016/j.atmosres.2007.11.019

[14] P. Dorta, "Las Inversiones Térmicas en Canarias," Investigaciones Geográficas, Vol. 15, 1996, pp. 109-124.

[15] H. Alexandersson and A. Moberg, "Homogenization of Swedish Temperature Data. Part I: Homogeneity Test for Linear Trends," International Journal of Climatology, Vol. 17, No. 1, 1997, pp. 25-34. http://dx.doi.org/10.1002/(SICI)1097-0088(199701)17:1< 25::AID-JOC103>3.0.CO;2-J

[16] H. A. Alexandersson, "A Homogeneity Test Applied to Precipitation Data," International Journal of Climatology, Vol. 6, No. 6, 1986, pp. 661-675. http://dx.doi.org/10.1002/joc.3370060607

[17] A. N. Pettitt, "A Nonparametric Approach to the ChangePoint Problem," Applied Statistics, Vol. 28, No. 2, 1979 pp. 126-135. http://dx.doi.org/10.2307/2346729

[18] R. Sneyers, "Sobre el Análisis Estadístico de las Series de Observaciones," OMM, Nota Técnica 143, OMM-N 415, Geneva, 1975

[19] T. K. Osborn, K. R. Briffa and P. D. Jones, “Adjusting 
Variance for Sample-Size in Tree-Ring Chronologies and Other Regional Mean Time Series," Dendrochronol, Vol. 15, 1997, pp. 89-99.

[20] B. D. Santer, T. M. L. Wigley, J. S. Boyle, D. J. Gaffen, J. J. Hnilo, D. Nychka, D. E. Parker and K. E. Taylor, "Statistical Significance of Trends and Trend Differences in Layer-Average Atmospheric Temperature Time Series," Journal of Geophysical Research, Vol. 105, No. D6, 2000, pp. 7337-7356. http://dx.doi.org/10.1029/1999JD901105

[21] E. Kalnay, M. Kanamitsu, R. Kistler, W. Collins, D. Deaven, L. Gandin, M. Iredell, S. Saha, G. White, J. Woollen, Y. Zhu, A. Leetmaa and R. Reynolds, "The NCEP/ NCAR 40-Year Reanalysis Project," Bulletin of American Meteorology Society, Vol. 77, No. 3, 1996, pp. 437-471. http://dx.doi.org/10.1175/1520-0477(1996)077<0437:TN $\mathrm{YRP}>2.0 . \mathrm{CO} ; 2$

[22] J. Hansen, R. Ruedy, J. Glascoe and M. Sato, "GISS Analysis of Surface Temperature Change," Journal of Geophysical Research, Vol. 104, No. D24, 1999, pp. 30997-31022. http://dx.doi.org/10.1029/1999JD900835

[23] P. Jones, T. Wigley and P. Kelly, "Variations in Surface Air Temperatures: Part 1. Northern Hemisphere, 18811980," Monthly Weather Review, Vol. 110, No. 2, 1982, pp. $59-70$.

http://dx.doi.org/10.1175/1520-0493(1982)110<0059:VIS ATP $>2.0 . \mathrm{CO} ; 2$

[24] D. R. Easterling, B. Horton, P. D. Jones, T. C. Peterson, T. R. Karl, D. E. Parker, M. J. Salinger, V. Razuvayev, N. Plummer, P. Jamason and C. K. Folland, "A New Look at Maximum and Minimum Temperature Trends for the Globe," Science, Vol. 277, No. 5324, 1997, pp. 364-367. http://dx.doi.org/10.1126/science.277.5324.364

[25] B. G. Liepert, "Observed Reductions of Surface Solar Radiation at Sites in the United States and Worldwide from 1961 to 1990," Geophysical Research Letters, Vol. 29, No. 10, 2002, pp. 61-1-61-4. http://dx.doi.org/10.1029/2002GL014910

[26] S. J. Smith, J. van Aardenne, Z. Klimont, R. J. Andres, A. Volke and S. Delgado, "Anthropogenic Sulfur Dioxide Emissions: 1850-2005," Atmospheric Chemistry and Physics, Vol. 11, 2011, pp. 1101-1116. http://dx.doi.org/10.5194/acp-11-1101-2011
[27] M. Wild, H. Gilgen, A. Roesch, A. Ohmura, C. N. Long, E. G. Dutton, B. Forgan, A. Kallis, V. Russak and A. Tsvetkov, "From Dimming to Brightening: Decadal Changes in Solar Radiation at Earth's Surface," Science, Vol. 308, No. 5723, 2005, pp. 847-850. http://dx.doi.org/10.1126/science.1103215

[28] M. Wild, "Global Dimming and Brightening: A Review," Journal of Geophysical Research: Atmospheres, Vol. 114 No. D10, 2009. http://dx.doi.org/10.1029/2008JD011470

[29] J. R. Magnus, B. Melenberg and C. Muris, "Global Warming and Local Dimming: The Statistical Evidence," Journal of the American Statistical Association, Vol. 106, No. 494, 2011, pp. 452-468.

http://dx.doi.org/10.1198/jasa.2011.ap09508

[30] M. P. McCormick, L. W. Thomason and C. R. Trepte, "Atmospheric Effects of the Pinatubo Eruption," Nature, Vol. 373, 1995, pp. 399-404. http://dx.doi.org/10.1038/373399a0

[31] C. Price, S. Michaelides, S. Pashiardis and P. Alpert, "Long Term Changes in Diurnal Temperature Range in Cyprus," Atmospheric Research, Vol. 51, No. 2, 1999 pp. 85-98. http://dx.doi.org/10.1016/S0169-8095(99)00022-8

[32] M. V. Marzol, "Fog Water Collection in a Rural Park in the Canary Islands (Spain)," Atmospheric Research, Vol. 64, No. 1-4, 2002, pp. 239-250. http://dx.doi.org/10.1016/S0169-8095(02)00095-9

[33] P. Cereceda, P. Osses, H. Larraín, M. Farías, M. Lagos, R. Pinto and R. Schemenauer, "Advective, Orographic and Radiation Fog in the Tarapacá Region, Chile," Atmospheric Research, Vol. 64, No. 1-4, 2002, pp. 262-271. http://dx.doi.org/10.1016/S0169-8095(02)00097-2

[34] L. Jin-Jia, S. K. Behera, Y. Masumoto and T. Yamagata, "Impact of Global Ocean Surface Warming on Seasonalto-Interannual Climate Prediction," Journal of Climate, Vol. 24, 2011, pp. 1626-1646. http://dx.doi.org/10.1175/2010JCLI3645.1

[35] F. González Taboada and R. Anadón, "Patterns of Change in Sea Surface Temperature in the North Atlantic during the Last Three Decades: Beyond Mean Trends," Climatic Change, Vol. 115, No. 2, 2012, pp. 419-431. http://dx.doi.org/10.1007/s10584-012-0485-6 